\title{
Innovation and Enterprise in Singapore Schools
}

\author{
Ng Pak Tee
}

Published online: 18 August 2006

(C) Springer Science+Business Media B.V. 2006

\section{Educ Res Policy Prac (2004) 3:183-198}

Due to a processing error, the references were published incorrectly in the abovementioned article. The correct references are given below (in bold).

\section{Pg 183}

Increasingly, the survival of nations will depend on how their citizenry can enhance their know-how and market it in the global market (Drucker, 1993; Ohmae, 1990). Globalisation appears to mandate education as a prime source of economic competitive advantage (Porter, 1990) and globalisation can have local effects on schools (Angus, 2004).

\section{Pg 185}

However, the Ministry of Education (MOE) is clear that $I \& E$ is not centred around creating entrepreneurs or letting them run businesses. Said Minister Tharman (2004b): What then is Innovation and Enterprise? Tharman (2004b) clarified:

The online version of the original article can be found at http://dx.doi.org/10.1007/s10671-004-8240-z.

N. P. Tee ( $\varangle)$

Policy and Leadership Studies Academic Group,

National Institute of Education,

Nanyang Technological University,

Singapore 
$\operatorname{Pg} 187$

Teachers are therefore caught in a dilemma between the push for innovation and the pull of the familiar (Walker and Walker, 1998). Tharman (2004a) acknowledged this:

\section{Pg 189}

Principals cannot afford to stray too far, so long as they are held accountable for their schools' performance in the national examinations (Tan, 2003). On this front, Tan (2003, p. 40) asked:

\section{Pg 190}

School leaders are thus very important. They will have to give the direction and find the balance. Tharman (2004a) said:

\section{Pg 193}

In an almost unprecedented move, senior career civil servant Ngiam Tong Dow questioned the assumption behind a number of key government policies such as housing and taxes in a hard-hitting speech to the Economics Society of Singapore (Teo, Tan and Lee, 2004).

\section{Pg 195}

Based on the organisational change model, school leaders and teachers could reflect on:

\section{Pg 197}

Hamel, G. (2000). Leading the Revolution. Boston Massachusetts: Harvard Business School Press. 